\title{
STUDY OF THE IMPACT OF DEVELOPMENT ACTIVITIES ON GROUNDWATER SYSTEM IN ABU SIFIERA AND MUBARAK WADIS, RED SEA COAST, EGYPT
}

\author{
Yehia L. Ismail", Ezz El-Din M. Al Tablawy and Amal A. Abel \\ Hafez \\ Department of Hydrology, Desert Research Center, El-Matareya, \\ Cairo, Egypt \\ *E-mail: yehiashehata@hotmail.com
}

he establishment and development processes in the
promising wadis of the Eastern Desert through
cooperation protocol between the Egyptian Ministry of Agriculture and World Food Program (WFP) in frame of Bedouins communities' development project, Red Sea Governorate (20042012), have attracted more attentions from the Egyptian government. So, the scientific management of the water resources in these wadis plays an outstanding role to achieve this target. This paper aims to evaluate the groundwater potentials in two promising wadis namely, Wadi Mubarak (75 km south El Qusier city) and Wadi Abu Sifiera $(10 \mathrm{~km}$ south El Shalateen city $)$. Hydrogeologically, the water bearing formation in Wadi Mubarak consists of fractured basement rocks. It is composed of older granodiorite and fractured metamorphic serpentinite rocks. In addition, the hydraulic parameter of the study aquifer reveals good potentiality and good capability to transmit water through it. On the other hand, the aquifer in Wadi Abu Sifiera is composed of wadi fill deposits of Quaternary aquifer, non-conformably overlie the weathered basement. The investigated aquifer displays show low groundwater potentiality, due to small thickness of saturated zone, low hydraulic conductivity as a result of heterogenic of lithofacies laterally and vertically and low rate of recharge. The aquifers behavior of both aquifers reveals continuous decrease in water level and deterioration of water salinity with time. This phenomenon could be attributed to the mismanagement of water resources and non-implementation of advanced harvesting techniques for surface runoff, as well as, the high rate of evaporation in the study area.

Keywords: groundwater, water bearing formations, hydraulic parameters, groundwater potentiality 
Groundwater resources planning and management in the promising wadis aims to optimal and sustainable use of these resources in different investments and establishment of Bedouin Communities Program through integrated water resources management plan. The major concern of this management is protection of groundwater resources quantitatively and qualitatively. Therefore, the aim of this work is evaluation of the role of groundwater resources for public water supply and agricultural purposes in the two promising wadis. Recently, more attentions have been directed towards the investigated wadis, through the cooperation between the Egyptian Ministry of Agriculture and World Food Program (WFP) in the frame of Bedouins communities' development project, Red Sea Governorate. Wadi Mubarak $\left(1182.5 \mathrm{~km}^{2}\right)$ lies $75 \mathrm{~km}$ south El Qusier city, while Wadi Abu Sifiera $\left(708 \mathrm{~km}^{2}\right)$ lies $10 \mathrm{~km}$ south El Shalateen city along the Red Sea coast. Wadi Mubarak has an economic importance due to the occurrence of gold and tin as economic minerals. On the other hand, Wadi Abu Sifiera has more attention through the implementation of sustainable development policy and improves the livelihood for the Bedouins in the investigated wadi. Meteorologically, the Eastern Desert occupies a portion of arid to semi-arid belt of Egypt. The average rainfall over the Eastern Desert is extremely low. The rainfall intensity decreases from north to south. During the period of heavy storms the maximum rainfall precipitation is about $28.5 \mathrm{~mm} /$ day (recorded in October, 1993), while the minimum rainfall precipitation is about $19.5 \mathrm{~mm} /$ day at Ras Banas station (Aglan, 2002). On the other hand, the evaporation in the Eastern Desert shows a propulsive increase towards the south. It ranges between $10 \mathrm{~mm} /$ day and $13 \mathrm{~mm} /$ day. The air temperature varies greatly from summer to winter and increases from north to south. It ranges between 22 and $26^{\circ} \mathrm{C}$. The relative humidity increasing southward and varying between 37 and $60 \%$.

Geologically, Wadi Abu Sifiera is surrounded from the western side by the basement rocks. Nubian sandstone is recorded near the water divide (northwestern portion of Wadi Hodein). Tertiary volcanic rocks are extruded at the foot slope of the Red Sea mountain shield. Miocene limestone occupies the Halayeb basin. The Quaternary deposits form the delta of the wadi and its main channel as wadi deposits. On the other hand, Wadi Mubarak belt is defined as a wedge shaped discrete region of east-west and northeast-southwest striking, highly deformed rocks of lower green schist metamorphic grade surrounded by less deformed metavolcanics, generally referred to as "undifferentiated metavolcanics" (Akaad et al., 1996). It is one of the longest low-grade volcano-sedimentary belts in the Eastern Desert and extends for over $65 \mathrm{~km}$ in length with an average width of about $20 \mathrm{~km}$. This highly deformed region extends from the Red Sea in the east to Gabel El Hadid in the west, which is well known for its iron deposits (Akaad et al., 1996). To the north, the belt is juxtaposed against Gabel El Umra granite Egyptian J. Desert Res., 66, No. 2, 287-304 (2016) 
complex. To the south, the belt is bound by Mubarak-Dabr MetagabbroDiorite Complex (Akaad et al., 1996). This complex is here referred to as the "diorite complex" (Fig. 1).

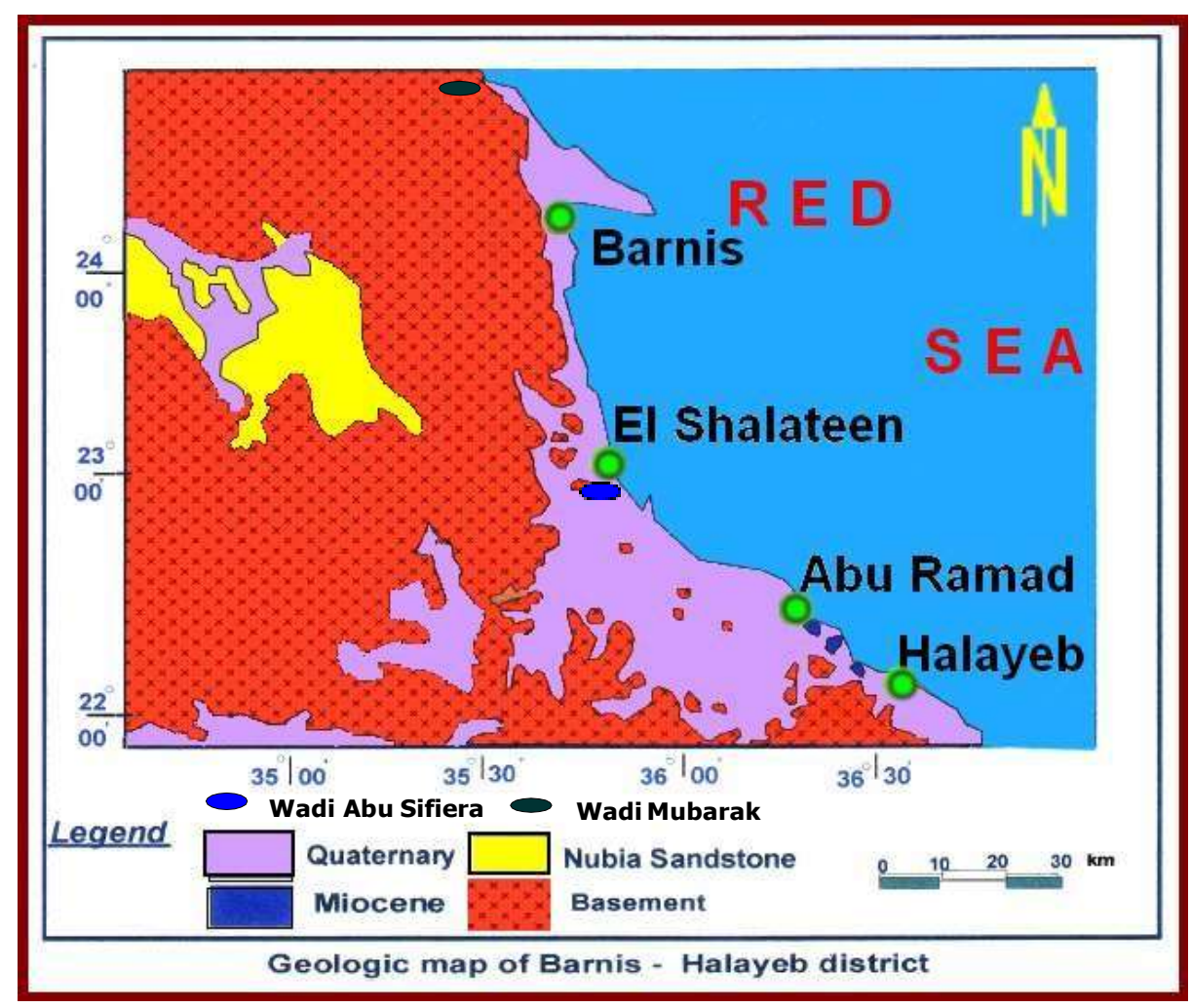

Fig. (1). Geological map of the southern eastern portion of the Red Sea coast.

Geomorphologically, the basin area of Wadi Abu Sifiera reaches $708 \mathrm{~km}^{2}$ and its drainage density (D) is 1.87 . This value indicates that the contribution of local rainfall to groundwater is expected to be limited. In addition, the wadi reveals high value of stream frequency $(\mathrm{F})$ equals 2.46 . It means that the basin has big tributary number per area, which tends to collect more runoff water and increases the rate of flow and discharge out of the basin. Therefore, the contribution of diversion dams will be useful for the conservation of runoff (Abu Zied, 2010).

The water bearing formation in Wadi Abu Sifiera consists of wadi fill deposits (Quaternary aquifer), non-conformably above the weathered basement. The groundwater is exploited from 8 hand dug wells (Figs. 2 and $3)$. 


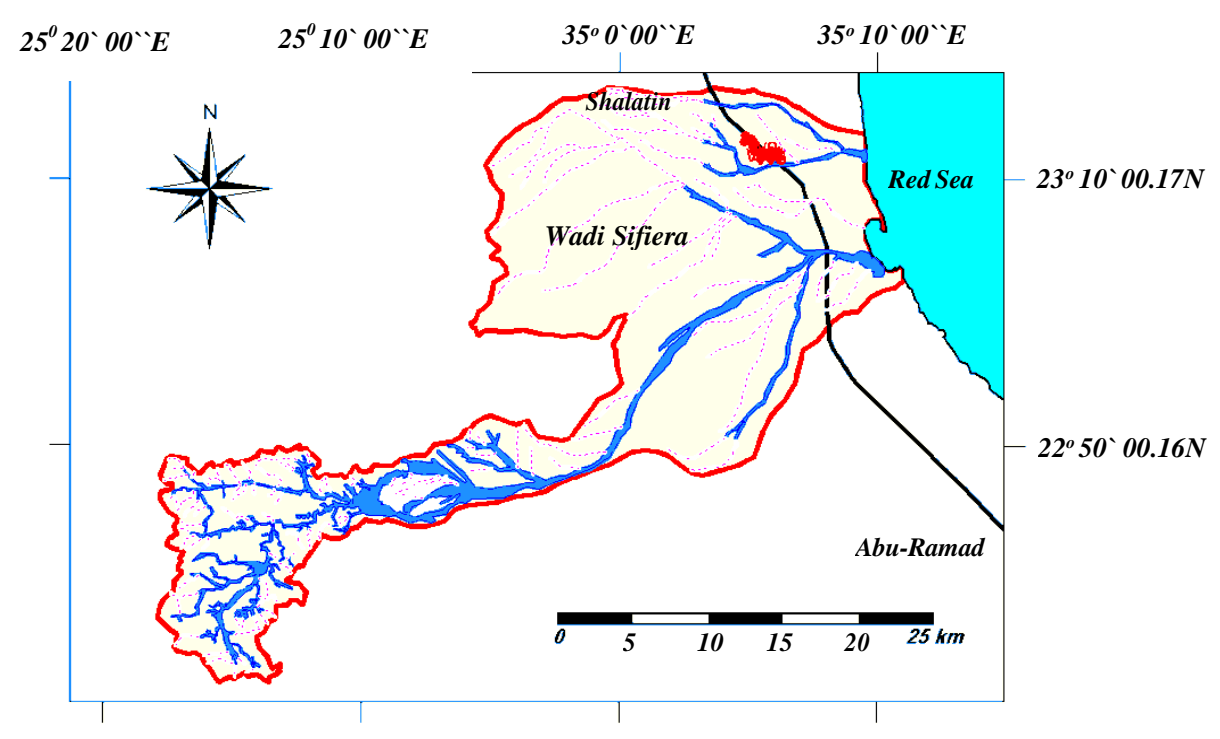

Fig. (2). Location map of Wadi Abu Sifiera catchment.

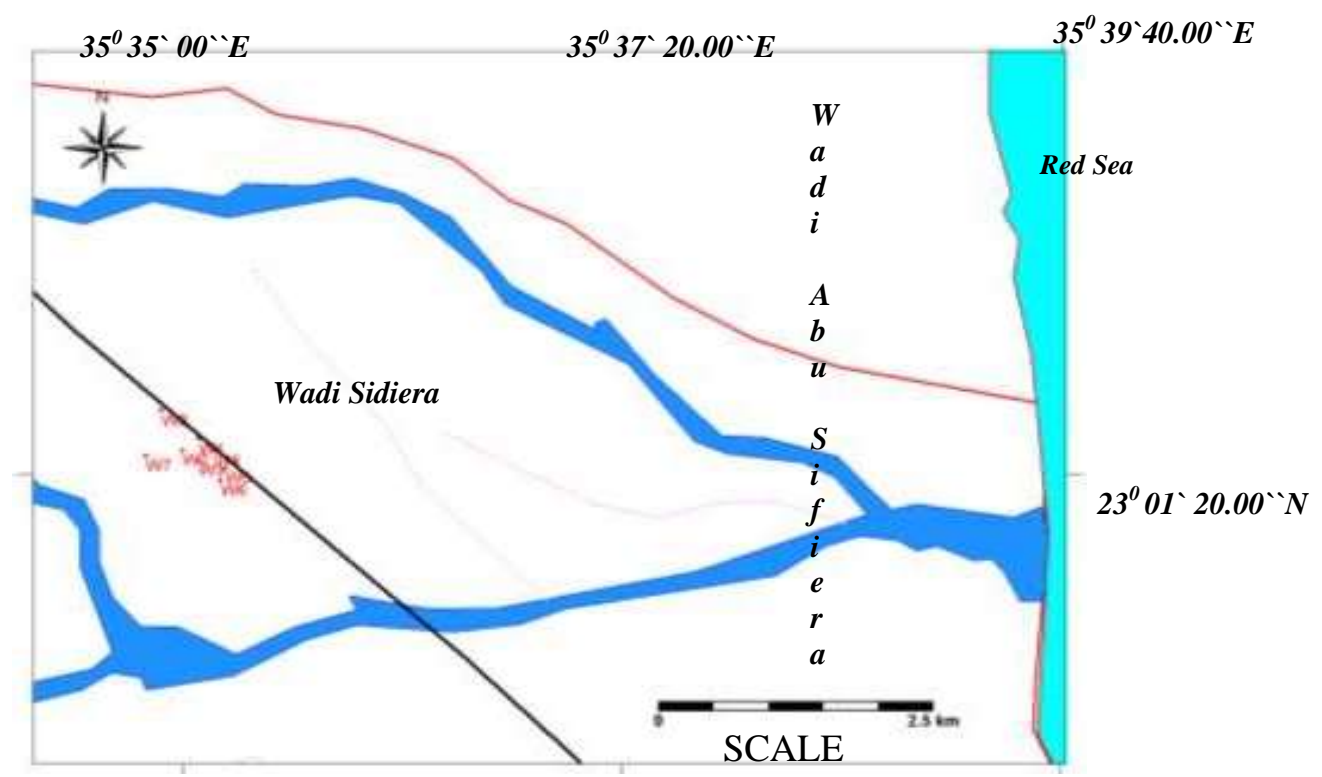

Fig. (3). Wells distribution map in the downstream portion of Wadi Abu Sifiera.

Egyptian J. Desert Res., 66, No. 2, 287-304 (2016) 


\section{MATERIALS AND METHODS}

In order to focus the light on the aquifer parameters of Wadi Abu Sifiera, two pumping tests have been carried out during the field works on wells nos. 5 and 8 using AQTESOLV Program for windows version 4 (Table $1)$.

Table (1). The technical data of water points tapping the Quaternary aquifer of Wadi Abu Sifiera.

\begin{tabular}{cccccc}
\hline $\begin{array}{r}\text { Well } \\
\text { name }\end{array}$ & $\begin{array}{c}\text { Well } \\
\text { diameter } \\
(\mathbf{m})\end{array}$ & $\begin{array}{c}\text { Aquifer } \\
\text { thickness( } \\
\mathbf{m})\end{array}$ & $\begin{array}{c}\text { Depth to } \\
\text { water } \\
(\mathbf{m})\end{array}$ & $\begin{array}{c}\text { Total } \\
\text { depth } \\
(\mathbf{m})\end{array}$ & $\begin{array}{c}\text { Salinity } \\
(\mathbf{p p m})\end{array}$ \\
$\mathbf{( 2 0 0 5})$ \\
\hline $\mathbf{A S - 1}$ & 2.5 & 1.45 & 21.70 & 23.15 & 6600 \\
$\mathbf{A S - 2}$ & 2.5 & 1.55 & 21.55 & 23.10 & 7000 \\
$\mathbf{A S - 3}$ & 3.0 & 1.70 & 21.30 & 23.00 & 7300 \\
$\mathbf{A S - 4}$ & 3.0 & 1.50 & 21.50 & 23.00 & 6600 \\
$\mathbf{A S - 5}$ & 3.0 & 1.65 & 21.20 & 22.85 & 7000 \\
$\mathbf{A S - 6}$ & 3.0 & 1.55 & 21.30 & 22.85 & 8300 \\
$\mathbf{A S - 7}$ & 3.0 & 1.80 & 21.20 & 23.00 & 6000 \\
$\mathbf{A S - 8}$ & 3.0 & 2.60 & 21.30 & 23.90 & 6650 \\
\hline
\end{tabular}

In addition, the hydraulic parameters of the fractured aquifer of Wadi Mubarak have been evaluated through four pumping tests carried out on four wells (Table 2).

Table (2). Technical data of water points tapping the study aquifer (August, 2008).

\begin{tabular}{ccccccc}
\hline $\begin{array}{c}\text { Well } \\
\text { no. }\end{array}$ & Well name & $\begin{array}{c}\text { Drilling } \\
\text { technique }\end{array}$ & Age & $\begin{array}{c}\text { Depth to } \\
\text { water (m) }\end{array}$ & $\begin{array}{c}\text { Total } \\
\text { depth } \\
(\mathbf{m})\end{array}$ & $\begin{array}{c}\text { Salinity } \\
\text { (ppm) }\end{array}$ \\
\hline 1 & Mubarak 1 & Dug well & Pre-Cambrian & 12.42 & 16.20 & 2900 \\
2 & Mubarak 2 & “ & “ & 13.53 & 15.20 & 2750 \\
3 & Mubarak 3 & “ & “ & 14.37 & 16.30 & 3000 \\
4 & Mubarak 4 & “ & “ & 18.92 & 23.60 & 3000 \\
5 & Umm El & & & 17.64 & 20.19 & 4073 \\
& Huweitat & “ & “ & 12.06 & 14.00 & 3341 \\
\hline
\end{tabular}

The monitoring process of aquifer behavior plays a tremendous and important role in sustainable development projects to avoid the deterioration of aquifer characteristics. In order to achieve this target, the periodical and seasonal water level and water salinity fluctuation have been monitored 
during the period from 2005 to 2010. On the other hand, the monitoring of water level for the water points of Wadi Mubarak has been carried out from 2008 to 2010.

\section{RESULTS AND DISCUSSION}

\section{Wadi Abu Sifiera}

\subsection{Aquifer parameters}

The obtained values were tabulated in table (3) and shown in figs. (4 and 5).

Table (3). The calculated values of the hydraulic parameters of the Quaternary aquifer of Wadi Abu Sifiera.

\begin{tabular}{cccccccc}
\hline $\begin{array}{c}\text { Well } \\
\text { No. }\end{array}$ & $\begin{array}{c}\text { Depth to } \\
\text { water } \\
(\mathbf{m})\end{array}$ & $\begin{array}{c}\text { Total } \\
\text { Depth } \\
(\mathbf{m})\end{array}$ & $\begin{array}{c}\text { Diameter } \\
(\mathbf{m})\end{array}$ & $\begin{array}{c}\text { Discharge } \\
\left(\mathbf{m}^{\mathbf{3}} / \mathbf{h}\right)\end{array}$ & $\begin{array}{c}\text { Total } \\
\text { drawdown } \\
(\mathbf{m})\end{array}$ & $\begin{array}{c}\text { Pumping } \\
\text { duration } \\
(\mathbf{m i n})\end{array}$ & $\begin{array}{c}\mathbf{T} \\
\left(\mathbf{m}^{2} / \mathbf{d a y}\right)\end{array}$ \\
\hline 5 & 21.27 & 22.85 & 2.05 & 1.33 & 1.25 & 75 & 3.3 \\
8 & 22.74 & 23.78 & 2.10 & 2.48 & 1.03 & 70 & 11.1 \\
\hline
\end{tabular}

According to Georhage classification (1979) (Table 4), it is obvious that the aquifer deposits have very limited potentiality and capability to transmit water through it. This could be attributed to the heterogenic of aquifer sediments laterally and vertically. These conditions give the chance for leaching and dissolution of terrestrial salts processes occurred, which finally reflect saline water type.

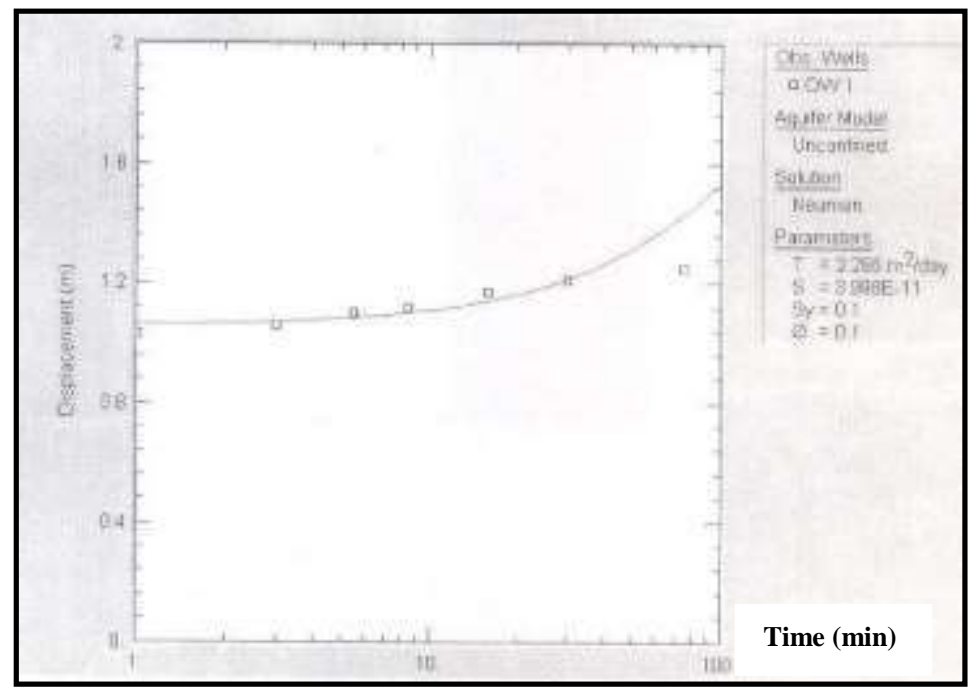

Fig. (4). Analysis of pumping test of well no. 5.

Egyptian J. Desert Res., 66, No. 2, 287-304 (2016) 


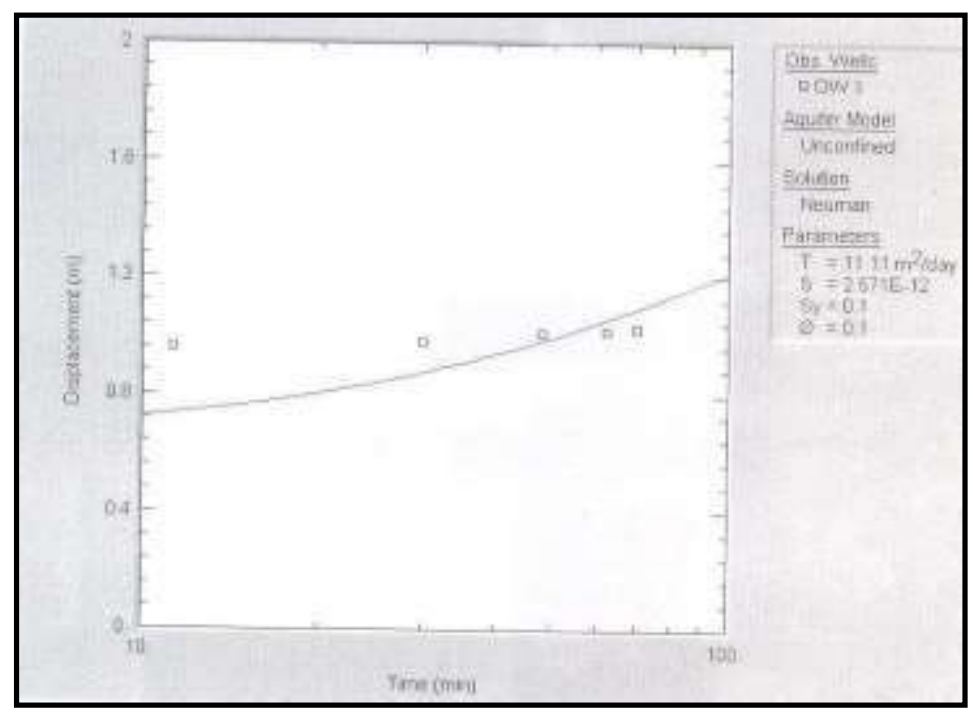

Fig. (5). Analysis of pumping test of well no. 8. using AQTESOLV Program for windows version 4. (Feb. 2006).

Table (4). The classification of the potentiality of the Aquifer on the basis of the transmissivity values 'T' (Georhage, 1979).

\begin{tabular}{cc}
\hline \multicolumn{2}{c}{ Aquifer Potentiality $($ Georhage, 1979$)$} \\
\hline Potentiality of The Aquifer & Transmissivity $\left(\mathbf{m}^{2} / \mathbf{d a y}\right)$ \\
\hline High & $>500$ \\
Moderate & $50-500$ \\
Low & $5-50$ \\
Very low & $0.5-5$ \\
Negligible & $<0.5$ \\
\hline
\end{tabular}

\subsection{Aquifer behavior}

Periodical monitoring of water level and water salinity for water points have been carried out during the period from 2005 to 2010 (Table 5 and Figs. 6 and 7). 
Table (5). Periodical monitoring of water level and water salinity for water points.

\begin{tabular}{cccccccc}
\hline Well & \multicolumn{9}{c}{ S.W.L. $(\mathbf{m})$} & \multicolumn{3}{c}{ Salinity (ppm) } \\
\cline { 2 - 8 } No. & June & August & October & January & June & August & October \\
& $\mathbf{2 0 0 5}$ & $\mathbf{2 0 0 8}$ & $\mathbf{2 0 0 9}$ & $\mathbf{2 0 1 0}$ & $\mathbf{2 0 0 5}$ & $\mathbf{2 0 0 8}$ & $\mathbf{2 0 0 9}$ \\
\hline 1 & 21.70 & 21.72 & 22.50 & 21.5 & 6600 & 6900 & 7000 \\
2 & 21.50 & 21.47 & 22.20 & 21.5 & 7000 & 7900 & - \\
3 & 21.30 & 21.50 & 22.15 & - & 7300 & 8100 & - \\
4 & 22.15 & 22.12 & 22.30 & 21.6 & 6600 & 7500 & - \\
5 & 21.20 & 21.27 & 22.20 & 21.3 & 7000 & 7300 & 7200 \\
6 & 21.30 & 22.21 & 22.90 & 21.3 & 8300 & 8500 & 9000 \\
7 & - & 22.27 & - & 22.0 & 6000 & 6900 & - \\
8 & 22.50 & 22.74 & 25.85 & 22.5 & 5650 & 7200 & 7000 \\
\hline
\end{tabular}

S.W.L.: Static Water Level

According to the obtained results, the water quality is mainly saline, in addition a gradually increase in water salinity accompanied by water level decrease from 2005 to 2009. This phenomenon could be attributed to low rate of recharge (sacristy of rainfall), as well as, high rate of evaporation, especially in the case of large diameter wells. Also, the leaching and dissolution of terrestrial salts processes as a result of low capability of aquifer sediments to transmit water through it. On the contrary, the excess of water recharge during the season of 2010 could be attributed to the shower of rainwater in that time, which has direct impact on the static water level and water salinity.

\section{Wadi Mubarak}

2.1. Morphometric parameters of Wadi Mubarak

In a trial to focus some light on the morphometric parameters of the study Wadi, a quantitative hydrogeomorphometric analysis have been carried out based on topographic maps with scale of 1:100,000.( Fig. 8). The obtained values are shown in tables (6 and 7) and fig. (9). 


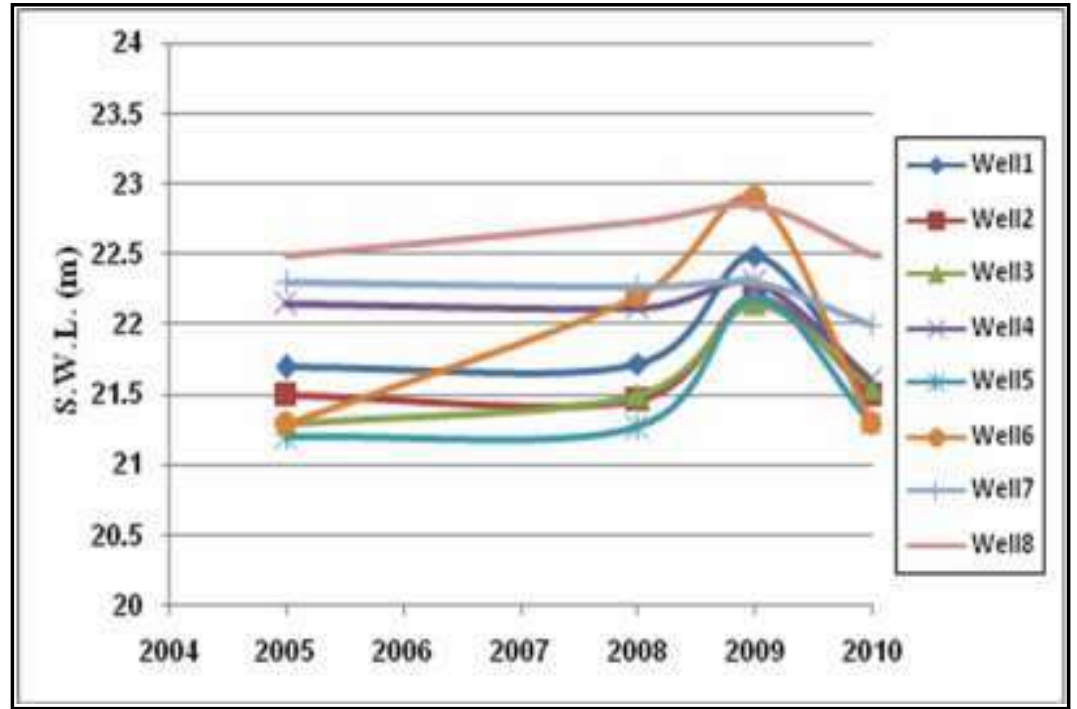

Fig. (6). Fluctuations of Static Water Level for Abu Sifiera wells.

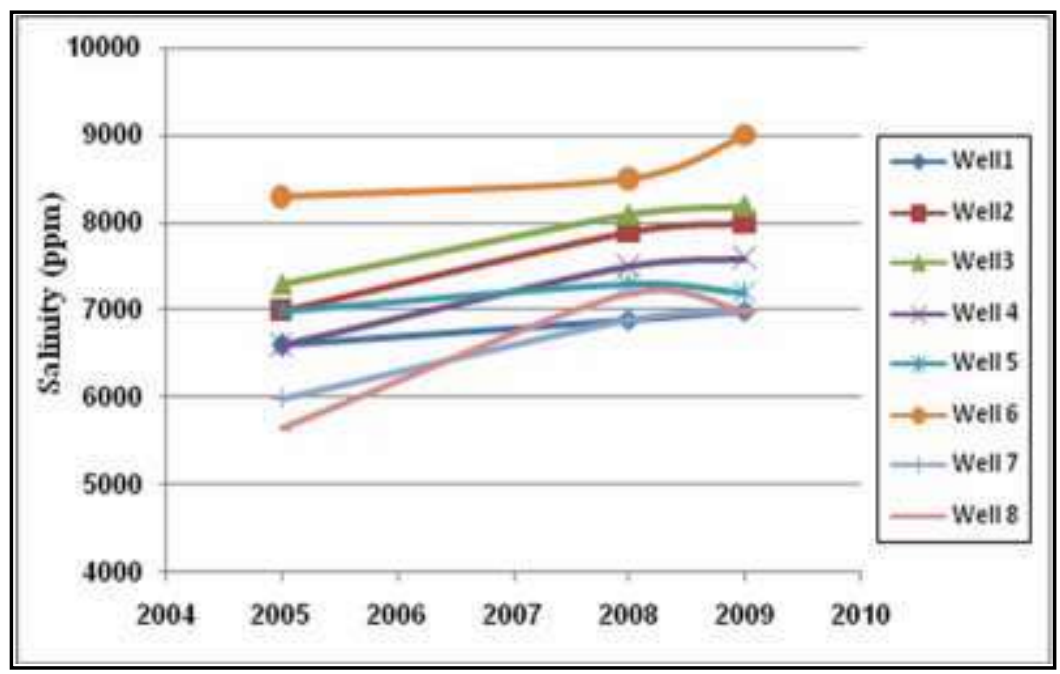

Fig. (7). Fluctuations of Water salinity for Abu Sifiera wells.

Egyptian J. Desert Res., 66, No. 2, 287-304 (2016) 


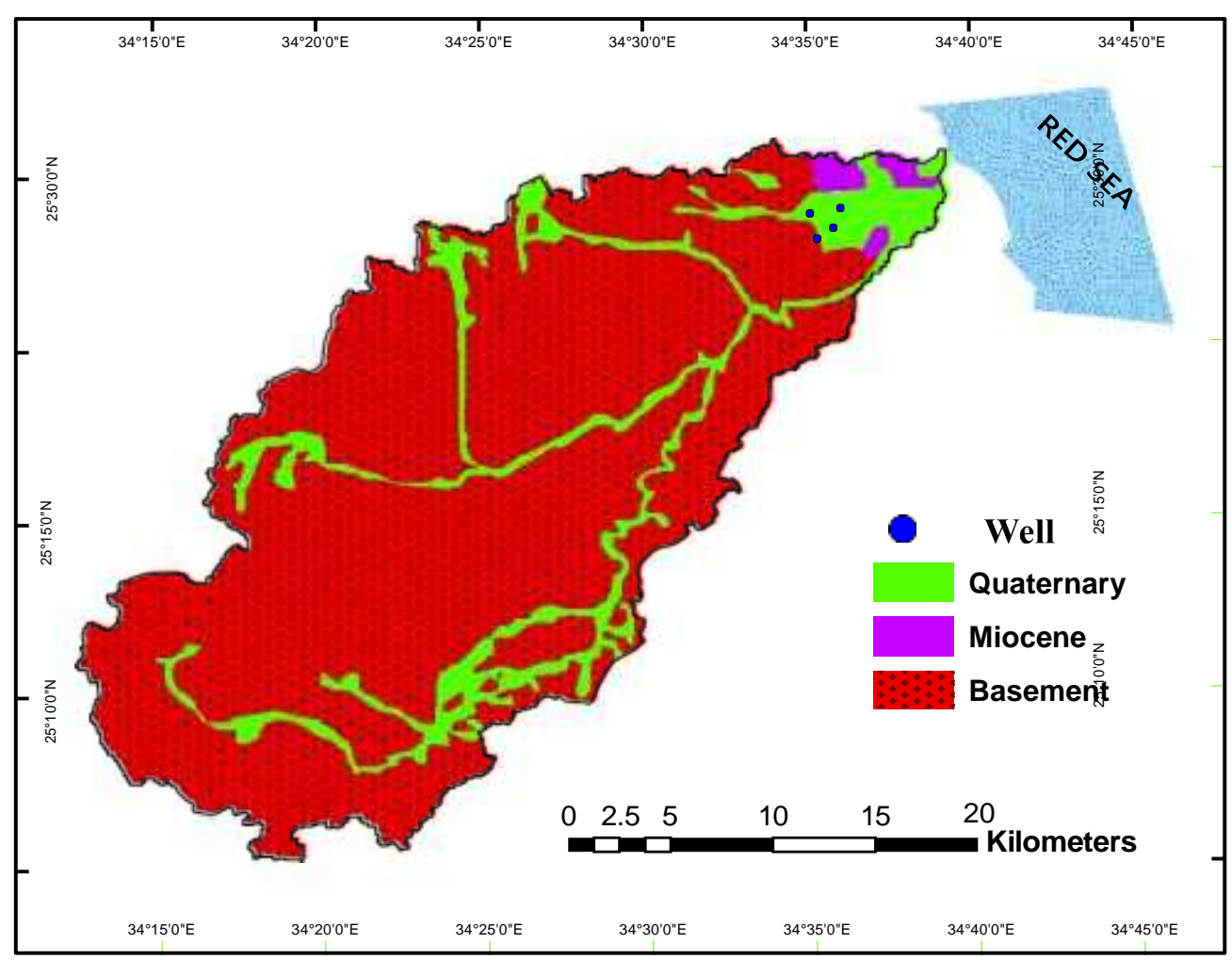

Fig. (8). Distribution of water points within Wadi Mubarak.

Egyptian J. Desert Res., 66, No. 2, 287-304 (2016) 


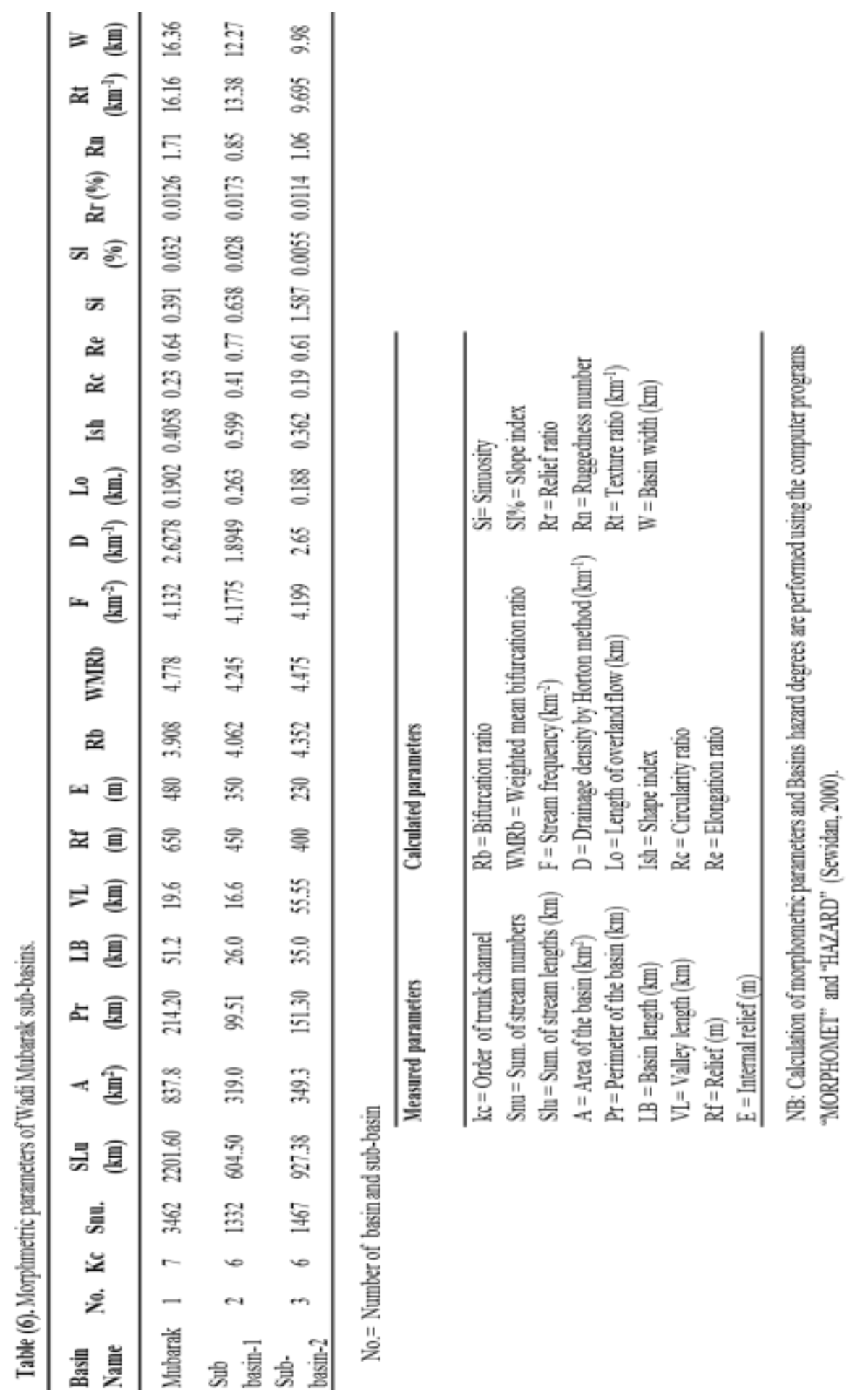

Egyptian J. Desert Res., 66, No. 2, 287-304 (2016) 


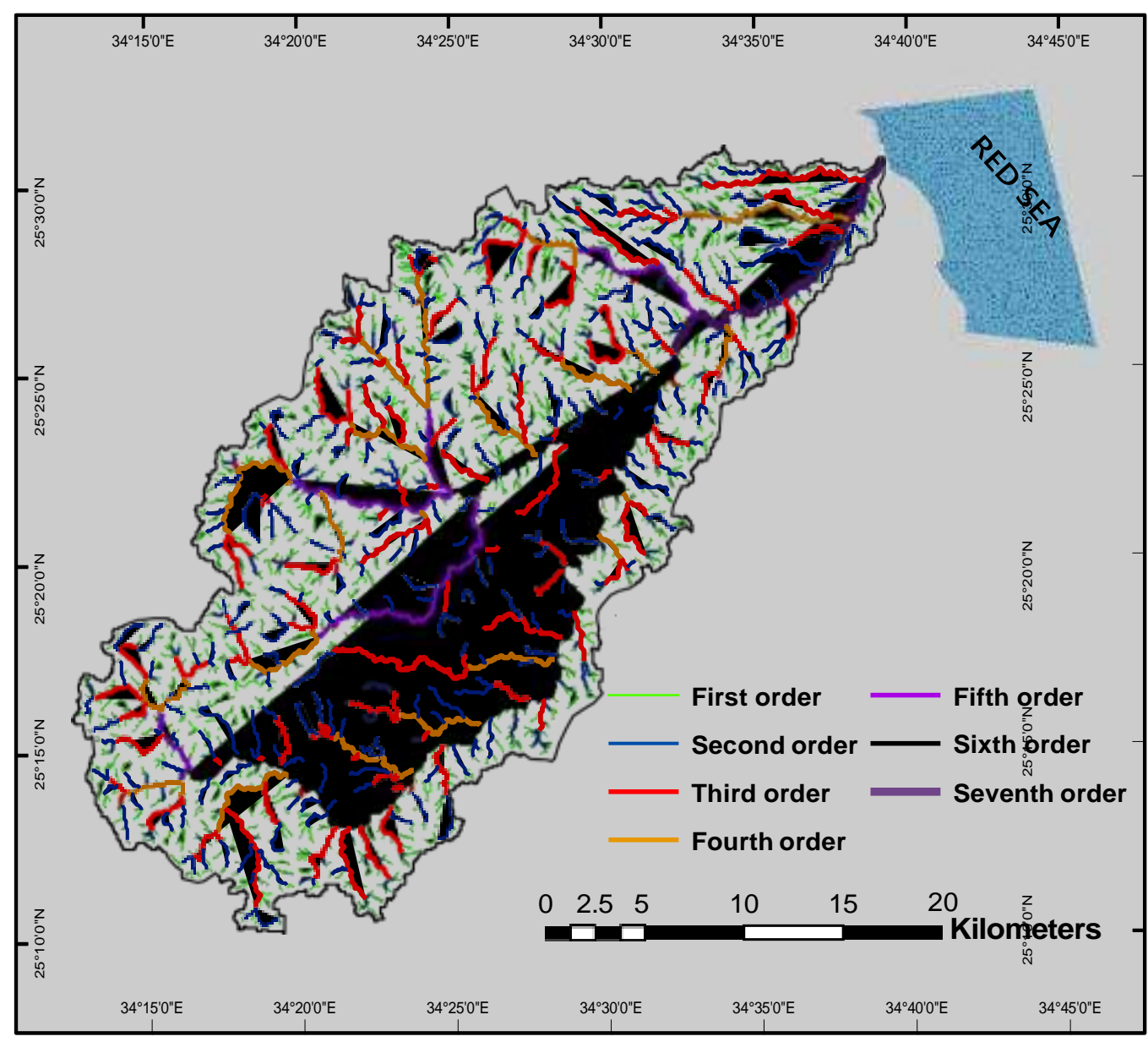

Fig. (9). Stream order of Wadi Mubarak.

Egyptian J. Desert Res., 66, No. 2, 287-304 (2016) 
Table (7). Hazard degrees of the effective parameters of the study basins.

Hazard degrees of the effective parameters

\section{Basin}

Basin

no.

degree

\begin{tabular}{lcccccccccccc}
\hline Basin name & & A & WMRb & F & D & SI & Ish & Rr & Rn & Rt & Sum. hazard \\
Sub basin-1 & 1 & 1 & 5 & 1 & 1 & 5 & 5 & 5 & 1 & 5 & 29 & 5 \\
Sub basin-2 & 2 & 5 & 1 & 5 & 5 & 1 & 1 & 1 & 5 & 1 & 25 & 1 \\
\hline
\end{tabular}

Based on the morphometric parameters of Wadi Mubarak, the optimum utilization of harvesting techniques for surface runoff plays an outstanding role for avoiding the damage of flash flood and in the same time reduce the velocity of runoff to give the chance to replenish the shallow aquifer in the wadi.

\subsection{Aquifer system}

The water bearing formation of the study wadi is mainly fractured basement rocks. It is composed of older granodiorite and fractured metamorphic serpentinite rocks. Groundwater and its movement of this aquifer are mainly controlled by the orientation and density of the fractural systems, which act as doming factors for water percolation. During the present inventory of the water points tapping the study aquifer, 6 water points were collected, as previously mentioned in (Table 2).

\subsection{The hydraulic parameters}

The calculated values of the hydraulic parameters of the fractured basement aquifer are shown in figs. (10,11, 12 and 13) and table (8).

Table (8). Calculation of the hydraulic parameters.

\begin{tabular}{lcccccc}
\hline $\begin{array}{l}\text { Well } \\
\text { name }\end{array}$ & $\begin{array}{c}\text { Depth } \\
\text { to water } \\
(\mathbf{m})\end{array}$ & $\begin{array}{c}\text { Total } \\
\text { depth } \\
(\mathbf{m})\end{array}$ & $\begin{array}{c}\text { Discharge } \\
\left(\mathbf{m}^{\mathbf{3} / \mathbf{d} a y}\right)\end{array}$ & $\begin{array}{c}\text { Total } \\
\text { drawdown } \\
(\mathbf{m})\end{array}$ & $\begin{array}{c}\text { Pumping } \\
\text { duration } \\
(\mathbf{m i n})\end{array}$ & $\begin{array}{c}\text { T } \\
\mathbf{m}^{2} / \mathbf{d a y}\end{array}$ \\
\hline Mubarak 1 & 12.42 & 16.20 & 96 & 0.070 & 240 & 736 \\
Mubarak 2 & 13.52 & 15.20 & 144 & 0.095 & 180 & 901 \\
Mubarak 3 & 14.37 & 16.30 & 96 & 0.100 & 300 & 857 \\
Mubarak 4 & 18.92 & 23.60 & 72 & 0.062 & 120 & 499 \\
\hline
\end{tabular}

According to Georhage classification (Table 4), the investigated aquifer reflects moderate to high potentiality. This could be attributed to the condensed fractures within the water bearing formation, which accelerate the movement of water through it. 


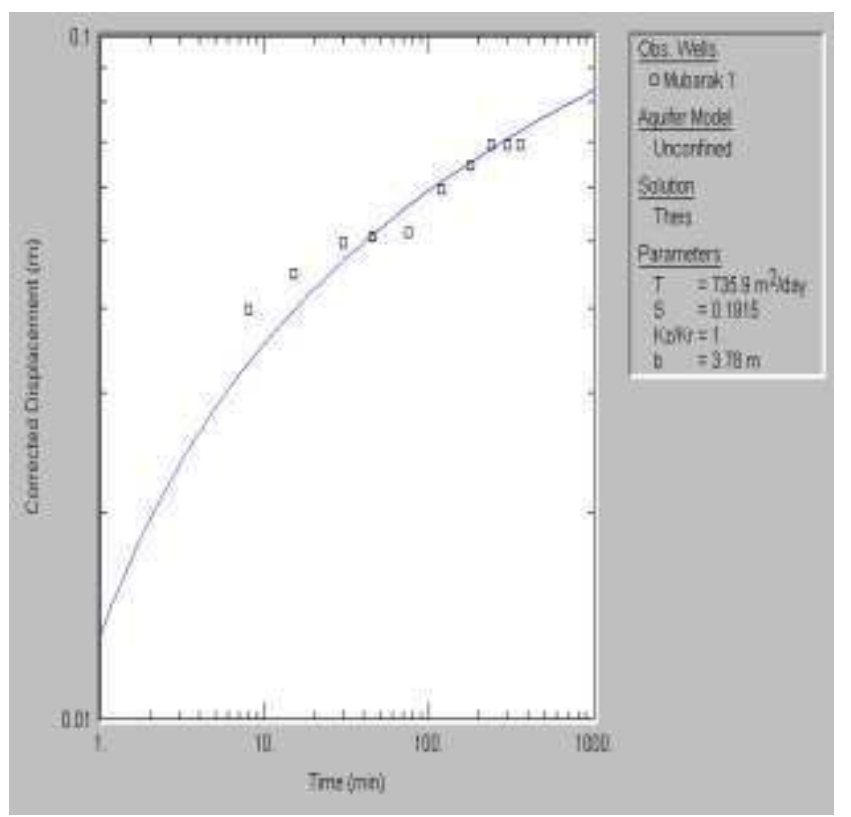

Fig. (10). Analysis of pumping test of Mubarak well no. 1.

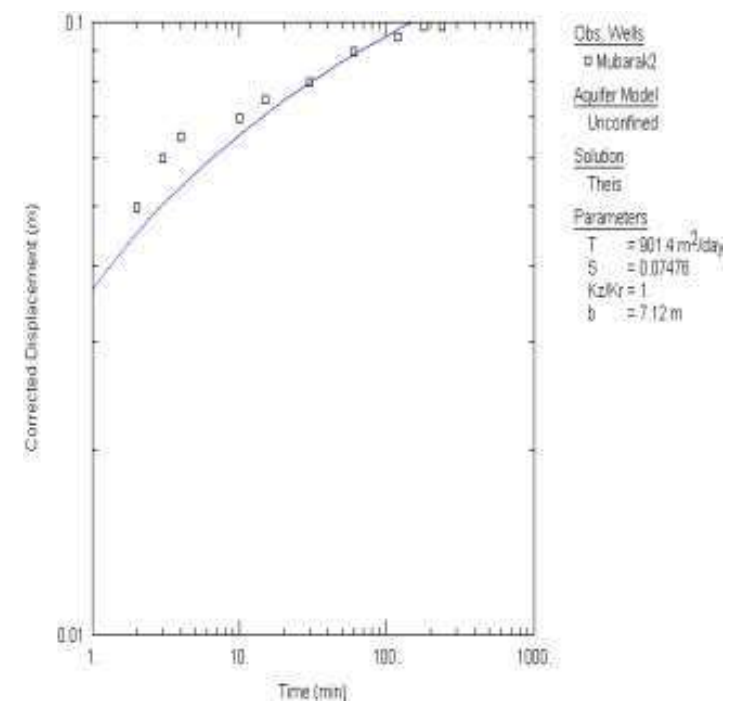

Fig. (11). Analysis of pumping test of Mubarak well no. 2.

Egyptian J. Desert Res., 66, No. 2, 287-304 (2016) 


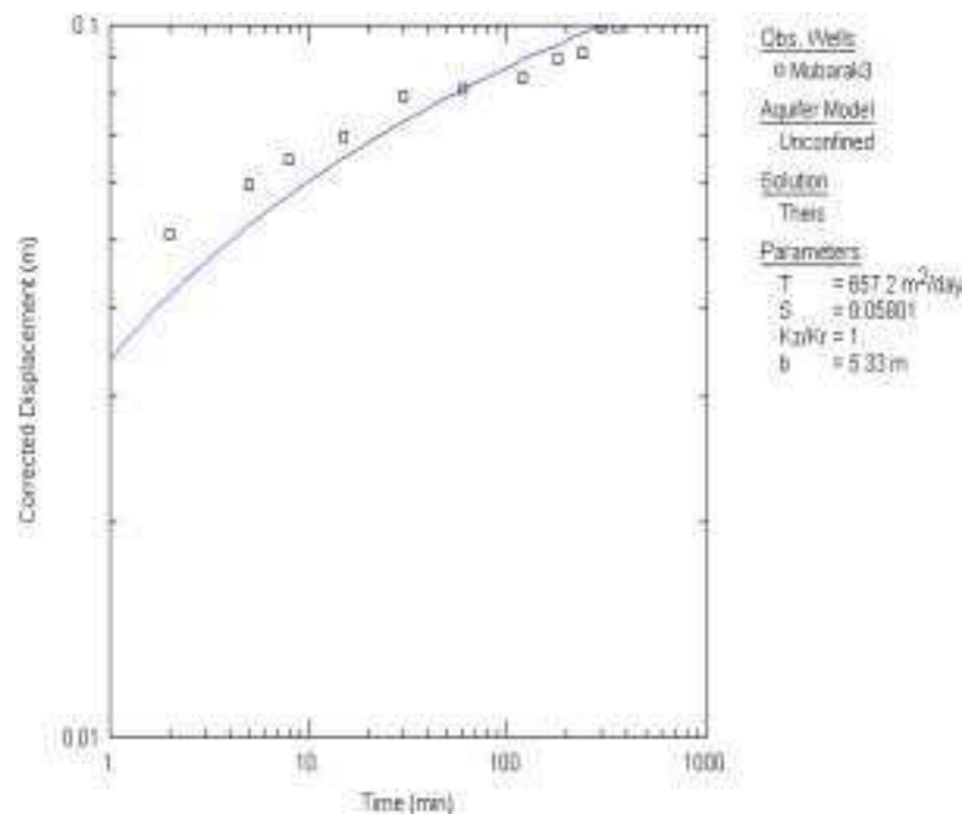

Fig. (12). Analysis of pumping test of Mubarak well no. 3.

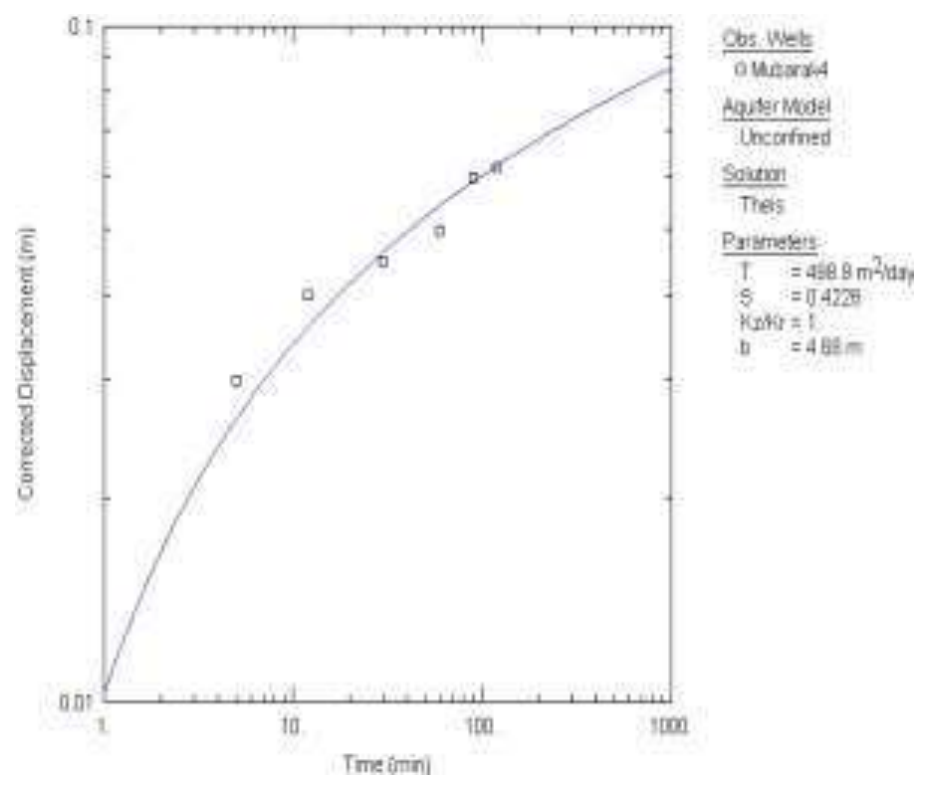

Fig. (13). Analysis of pumping test of Mubarak well no. 4. 


\subsection{Aquifer behavior}

In order to focus some light on the aquifer behavior, the monitoring of water level for the water points have been carried out from 2008 to 2010 (Table 9 and Fig. 14).

Table (9). Monitoring of water level for water points in Wadi Mubarak.

\begin{tabular}{lccccc}
\hline $\begin{array}{c}\text { Well } \\
\text { Name }\end{array}$ & $\begin{array}{c}\text { Total } \\
\text { depth } \\
\text { (m) }\end{array}$ & $\begin{array}{c}\text { Depth to } \\
\text { water } \\
\text { (August 2008) }\end{array}$ & $\begin{array}{c}\text { Depth to } \\
\text { water } \\
\text { (Feb. 2009) }\end{array}$ & $\begin{array}{c}\text { Depth to } \\
\text { water } \\
\text { (Feb. 2010) }\end{array}$ & $\begin{array}{c}\text { Depth to } \\
\text { water } \\
\text { (July 2010) }\end{array}$ \\
\hline Mubarak-1 & 16.20 & 12.42 & 12.70 & 12.90 & 12.90 \\
Mubarak-2 & 20.65 & 13.53 & 13.55 & 13.90 & 14.00 \\
Mubarak-3 & 19.17 & 14.37 & 14.55 & 14.70 & 14.80 \\
Mubarak-4 & 23.60 & 18.92 & 19.00 & 19.10 & 19.30 \\
\hline
\end{tabular}

Generally, the water quality is mainly brackish water and there is a continuous decrease in static water level with time. This situation could be attributed to the mismanagement of water resources in the pilot area and unimplementation of advanced harvesting techniques for surface runoff to give the chance for replenishment of shallow aquifer with rain water. Therefore, the management of water resources in the study area is very important to achieve and conserve the sustainable development processes.

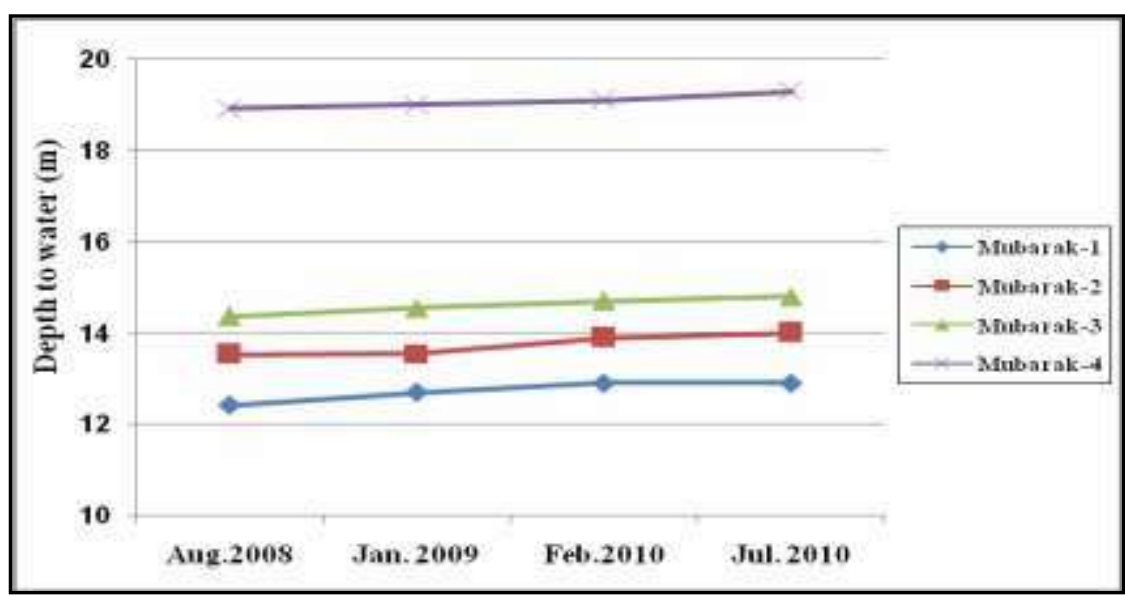

Fig. (14). Periodical monitoring of depth to water of wadi Mubarak wells.

\section{CONCLUSION AND RECOMMENDATIONS}

Management of wadi system is a very complex issue. As known, the system has two opposite faces, either beneficial or destructive. Both faces must be taking into consideration in management process, which should maximize benefits of the one and minimize dangers of the other. Bearing in 
mind that the complexity comes from the sustainability objective of the benefits against the low potentiality of the wadi water yield. These issues, together with economic aspects taking into consideration in arid and semiarid regions.

The main management factors in the study wadis can be summarized as follows:

1. Water storage, groundwater extraction and conjunctive use are the main management's keys. Flood hazard protection, sedimentation, evaporation problems, and environmental impacts and socio- economic measures are the main management concerns. Consequently, the sustainable flood water utilization provides the necessity of saving this water for longer period and wider uses. Accordingly, natural and artificial groundwater recharge represents the hope of achieving sustainable development that can be built on flood water.

2. The artificial recharge of groundwater through detention and storage dams during flood storms is highly recommended.

3. The conjunctive use of surface and groundwater is essential for management of the wadi system based on optimize benefits, minimize dangers and sustainability.

\section{REFERENCES}

Abu Zied, K.A. (2010). Evaluation of water resources of some drainage basins in the area between El Quseir and El Shalateen, Red Sea Coast, Eastern Desert. Ph.D Thesis, Fac. Sci., Al Azhar Univ., $265 \mathrm{pp}$.

Aglan, O.Sh. (2002). Geology of water resources in Wadi Hodein basin, south east of the Eastern Desert, Egypt. Ph.D Thesis, Fac. Sci., Ain Shams Univ., 212 pp.

Akaad, M.K., A.M. Noweir and A.M. Abu El Ela (1996). Geology of the Pan- African basement rocks of the Jabal El Hadid-Wadi Mubarak district, E.D., Egypt, covering parts of sheets NG 36 G 3, 6 and NG 36 H 1, 4. Geol. Surv. Egypt, 73: 78.

AQTESOLV (AQuifer TEst SOLVer) (2006). In "AQTESOLV for Windows Version 4 User's Guide" Duffield, G.M. (Ed.). Hydro- SOLVE, Inc. 2303 Horseferry Court, Reston, VA. P. $20191-2739$.

Georhage, A. (1979). In "Processing and Synthesis of Hydrogeological Data". Abacus Press, 390 pp. 


\section{دراسة تاتير الأنثطة التنموية عل نظم المياة الجوفية بواديي أبو سفيرة

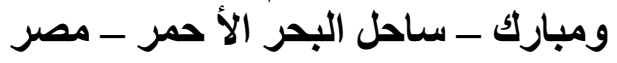

\section{يحيى لطفى إسماعيل"، عز الدين محمود الطبلاوي وأمل على عبد الحافظ

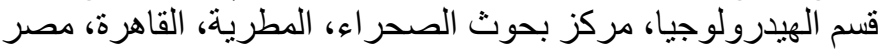

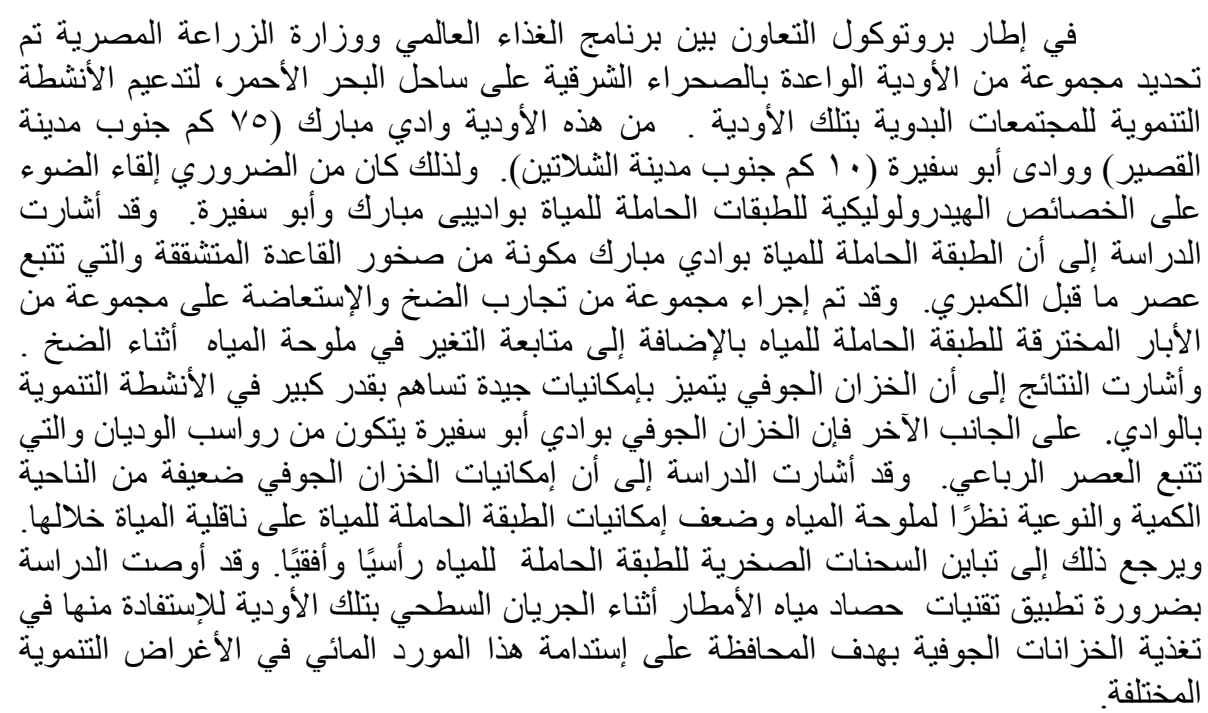

Egyptian J. Desert Res., 66, No. 2, 287-304 (2016) 